\title{
Physicochemical properties of tropical forest top soil in relation to depth in western Nepal
}

\author{
B. Gautam ${ }^{1 *}$ and M. K. Chettri ${ }^{1}$
}

Information on soil properties with regards to forest soil-depth are important for sustainable management of forest. The present study investigated the physicochemical properties of the top soil $(0-30 \mathrm{~cm}$ depth) in the three forests, viz. i) the Terai Shorea Forest (Bardia National Park), ii) the Evergreen Riverine Forest (Bardia National Park) and iii) the Puraina CF (Kailali district) of western Nepal. In the tropical forests of western Nepal, the soil texture is, moreover, loamy sand to sand. The soil bulk density ranged from $1.33-1.63 \mathrm{gm} \mathrm{cm}^{-3}$, and slightly increased with the increase in the soil-depth. The soil $\mathrm{pH}$ value ranged from 5.77-7.36. The soil organic carbon, total nitrogen $(\mathrm{N})$, available phosphorus $(\mathrm{P})$, and available potassium $(\mathrm{K})$ were found to be in the ranges of $0.54-1.64 \%, 0.04-0.14 \%, 4.84-31.72 \mathrm{~kg} \mathrm{ha}^{-1}$, and $204.35-557.44 \mathrm{~kg}$ $\mathrm{ha}^{-1}$, respectively, and all these values decreased with the increase in the soil-depth in both the forests of the protected area; however, this decreasing trend of the soil nutrients with the increase in the soil-depth was not observed in the Puraina CF as the values of the soil nutrients were lower within $0-10 \mathrm{~cm}$ in the CF. The soil nutrients with all the depths were found to be the highest in the Terai Shorea Forest. The lower values of the soil nutrients in the Puraina CF were the result of resource extraction.

Keywords: Forest soil, management practice soil properties, soil nutrients, top soil

$\mathrm{F}$ orest soils play a vital role in the global carbon cycle (Detwiler and Hall, 1988; Jabaggy and Jackson, 2000). Most of the soil organic carbon (SOC) is stored in the upper layers (UNEP, 2012; Spain et al., 1983; Burke et al., 1989), and are at a high risk of emission to the atmosphere due to disturbances and land use changes (Lal, 2010).

Soil fertility, an important factor which determines the growth of plants depends on the concentration of $\mathrm{N}, \mathrm{P}$, and $\mathrm{K}$ organic and inorganic materials, micronutrients and water. Lack of nutrient inputs is a major factor in soil degradation. Understanding of soil chemical reaction and processes is essential for developing innovative resource management strategies, and understanding and regulating the behaviour of the terrestrial ecosystem at regional and global scale (Tale and Ingole, 2015).
Information on soil properties with regards to forest soil-depth are important for sustainable management of forest. Soil productivity, health, sustainability, sequestration and emission potentials can be assessed by quantifying SOC (Vashum et al., 2016). Vertical distribution of SOC in relation to vegetation and land use is less understood (Jabbagy and Jackson, 2000). The soil carbon studies conducted in Nepal mainly focused on its relation with land use (Awasthi et al., 2005; Bajracharya et al., 2004, 2015; Dahal and Bajracharya, 2012). The tropical forest soils of western Nepal are less studied. Hence, the present study aims to investigate the top soil physiochemical properties in the tropical forests of western Terai region of Nepal in relation to depth.

1 Department of Botany, Amrit Campus (T.U.), Kathmandu. *Email: gautambikash2007@gmail.com 


\section{Materials and methods}

\section{Study area}

The present study was conducted in the three forests, viz. i) the Terai Shorea Forest situated in the south-western sector of the Bardia National Park (BNP) in western Nepal, ii) the Evergreen Riverine Forest situated in the south-western sector of the BNP, and iii) the Puraina Community Forest (CF) situated in Kailali district in western Nepal. The Bardia National Park is located between $28^{\circ} 17^{\prime}-28^{\circ} 40^{\prime} \mathrm{N}$ latitudes, and between $81^{\circ} 12^{\prime} \mathrm{E}-81^{\circ} 43^{\prime}$ E longitudes. Similarly, Puraina Community Forest (CF) is located between $28^{\circ} 39^{\prime}$ $\mathrm{N}-28^{\circ} 40^{\prime} \mathrm{N}$ latitudes and $81^{\circ} 00^{\prime} \mathrm{E}-81^{\circ} 01^{\prime} \mathrm{E}$ longitudes.

The Annual precipitation in the Tikapur Station, situated at $140 \mathrm{~m}$ above the mean sea level in Kailali district, was $1,669 \mathrm{~mm}$ (average of 1987-2017, DoHM, 2019). Most of the total precipitation were found to have occurred during June-September while the least during November-December (Figure 1). The average maximum and minimum temperatures recorded during the period of $1987-2017$ were $30.8^{\circ} \mathrm{C}$ and $17.6^{\circ} \mathrm{C}$, respectively (DoHM, 2019). The study was conducted in $2018 \mathrm{~A}$. D.

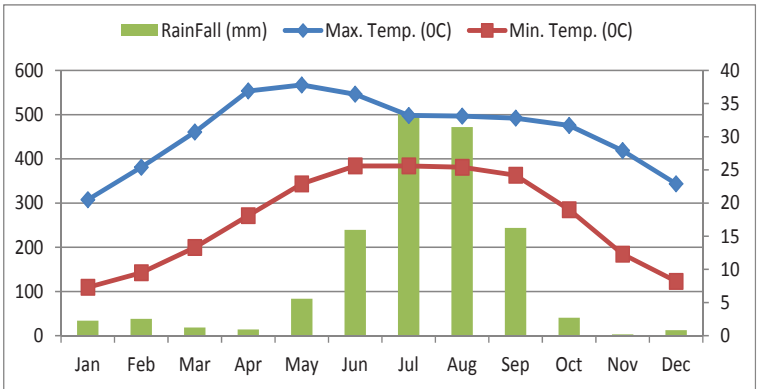

Figure 1: The average monthly temperature and rainfall data of Tikapur Station, Kailali district during 1987-2017 (Source: DoHM, 2019)

The Terai Shorea Forest is mainly dominated by Shorea robusta followed by Terminalia alata (Shrestha and Jha, 1997; Giri et al., 1999). The Evergreen Riverine Forest is dominated mainly by four tree species, viz. Syzygium cumini, Mallotus philippensis, Ficus glomerata and Schleichera oleosa (Shrestha and Jha 1997; Giri et al., 2001).
There is no resource extraction from the Terai Shorea and Riverine forests in the protected areas. According to Gautam (2019), the Puraina $\mathrm{CF}$ is mainly dominated by $T$. alata followed by Anogeissus latifolius, S. robusta and S. cumini. According to the Puraina CF User Group, this CF occupied an area of 189.21 ha, and the CF User Group included 540 families in 2073 B.S. (Figure 2 and 3). The settlements around the area were growing rapidly, increasing pressure in the forest. Although, cattle grazing and resource extraction were banned by the authorities, illegal logging and resource extraction were still the main challenges. According to the locals, forest fire prevention/control and plantations in the barren areas were the positive approaches initiated by the CF User Group.

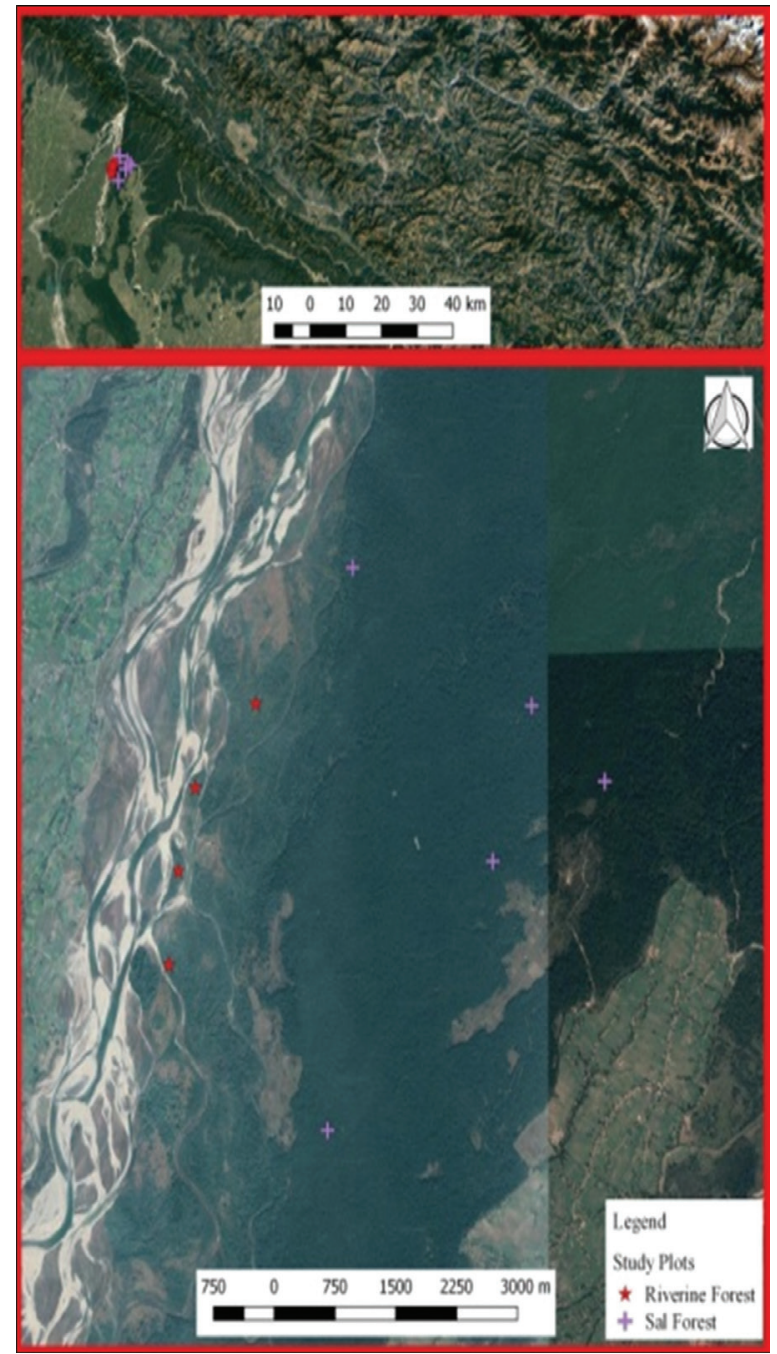

Figure 2: Satellite imagery of the Puraina CF (retrieved from the Google Earth in Dec, 2018) showing the locations of the sample plots 


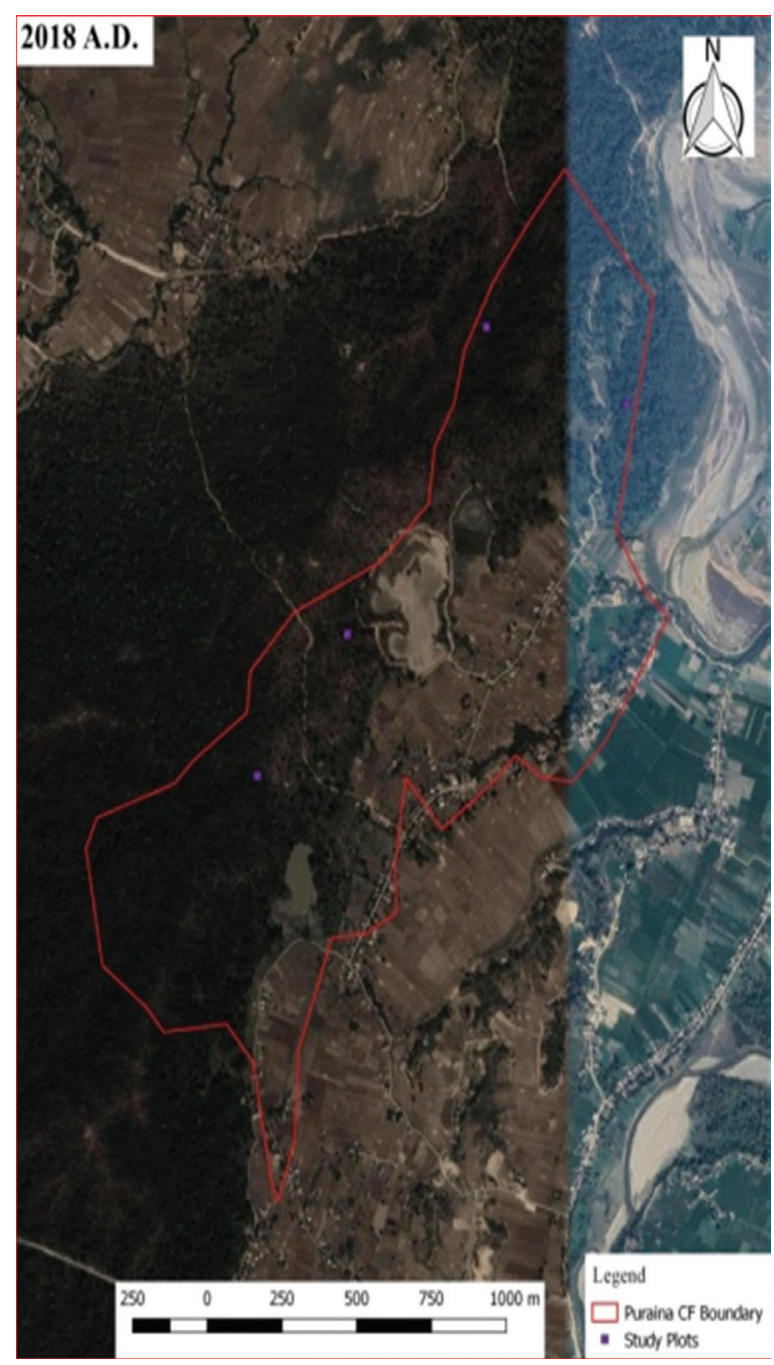

Figure 3: Satellite imagery of the Bardia National Park (retrieved from the Google Earth in Dec, 2018) showing the locations of the sample plots

\section{Soil sampling}

The soil sampling was conducted in October, 2018. Altogether, 13 plots, each of $500 \mathrm{~m}^{2}$, were taken into consideration; out of the total 13 plots, 5 plots were laid out in the Terai Shoera Forest, 4 plots in the Evergreen Riverine Forest, and 4 plots in the Puraina CF. Within each plot, five quadrats, each of $1 \mathrm{~m} \times 1 \mathrm{~m}$ size were laid using stratified random design. The sample plots were randomly marked on the basis of frequent observations. From each quadrat, soil samples from the depths of $0-10 \mathrm{~cm}, 10-20 \mathrm{~cm}$ and $20-30 \mathrm{~cm}$ were collected; three composite soil samples, one for each depth category, were prepared for each plot. Hence, a total of 39 composite soil samples (13 for each depth category) were prepared and collected.

\section{Soil analysis}

The laboratory analysis of the soil samples were carried at Amrit Campus (Kathmandu) and Agricultural Technology Centre (Lalitpur). The soil samples were analysed for bulk density using the methodology of Blake and Hartge (1986). Similarly, the SOC was determined using the Walkley and Black Rapid Titration Method (Walkley and Black, 1934) while the total Nitrogen, the available Phosphorus and the Available Potassium were determined by adopting the Kjeldahl Method, the Olsen's Bicarbonate Method, and the Flame Photometer Method, respectively. The soil texture was determined using the Sieve Method, and the soil $\mathrm{pH}$ was determined electronically, on a direct-reading $\mathrm{pH}$ meter, using a saturated potassium chloride calomel reference electrode.

The One-way ANOVA followed by Tukey's HSD (honestly significant difference) Test was conducted for the soil parameters using the $\mathrm{R}$ Software (version 3.5.1).

\section{Results and discussion}

\section{Physical properties}

\section{Soil texture}

The soil texture was found to be, moreover, loamy sand to sand in all the studied forests. The mean sand contents at all depths $(0-10 \mathrm{~cm}$, $10-20 \mathrm{~cm}$ and $20-30 \mathrm{~cm}$ ) were found to be within the range of $82.79-92.31 \%, 72.88-90.76 \%$, and $77.30-85.69 \%$ in the Terai Shorea Forest, the Riverine Forest and the Puraina CF, respectively. Similarly, the mean silt and clay contents at all depths were found to be within the range of $5.55-6.41 \%$ silt and $1.35-4.8 \%$ clay in the Terai Shorea Forest, $6.65-12.56 \%$ silt and $1.92-14.56 \%$ clay in the Riverine Forest, and $5.39-8.82 \%$ silt and $7.35-13.87 \%$ clay in the Puraina CF. The vertical differences in the percentages of sand, silt, and clay were found to be statistically insignificant for all the three study area. The comparison of the soils at all depths of all the three studied forests showed that the difference in the percentages of sand, silt and clay were all statistically insignificant, except clay\% 
at $10-20 \mathrm{~cm}$ depth differed significantly ( $<<$ 0.05 ) among the three study area. The percentage of clay at $10-20 \mathrm{~cm}$ depth in the Puraina CF was found to be significantly higher $(13.87 \%, \mathrm{p}<$ $0.05)$ than that in the Terai Shorea Forest $(1.35 \%$, $\mathrm{p}<0.05)$ at the same depth.

\section{Soil bulk density}

The mean soil bulk density slightly increased with the increase in depth in all the three studied forest which is because the soil gets more compact with the increase in its depth. The soil bulk densities at all depths in the three study sites area were in the range of $1.33-1.58 \mathrm{gm} \mathrm{cm}^{-3}, 1.35-1.58 \mathrm{gm} \mathrm{cm}^{-3}$, and $1.45-1.63 \mathrm{gm} \mathrm{cm}^{-3}$, respectively (Table 1 ). The bulk densities at all depths in the Puraina CF were found to be slightly higher than that Terai Shorea Forest except at $10-20 \mathrm{~cm}$ depth where the bulk density of both the forests recorded equal value i.e. $1.58 \mathrm{gm} \mathrm{cm}^{-3}$. Riverine forest recorded the least value for bulk density at all depths. It was found that the bulk density value of Terai Shorea Forest and Puraina CF (1.58 $\mathrm{gm} \mathrm{cm}^{-3}$ in both forests) at $10-20 \mathrm{~cm}$ was found to be significantly higher ( $\mathrm{p}$ $<0.05)$ than in the Riverine forest $\left(1.35 \mathrm{gm} \mathrm{cm}^{-3}\right)$ at the same depth. The vertical difference in the bulk densities of all the three forests was found statistically insignificant.

\section{Chemical properties}

\section{Soil pH}

The mean soil $\mathrm{pH}$ at all depths was found to be in the range of 5.77-5.80, 7.11-7.36, and 6.36-6.50 in the Terai Shorea Forest, the Evergreen Riverine Forest, and the Puraina CF, respectively. The Oneway ANOVA showed that the vertical differences among the soil $\mathrm{pH}$ were statistically insignificant in all the three different forest study sites; however, the differences among the soil $\mathrm{pH}$ values at all depths in the three different forest study areas were statistically significant $(\mathrm{p}<0.05$, Table 1$)$.

The soils were more acidic in the Terai Shorea Forest than in the Puraina CF; however, the soils in the Riverine Forests were slightly alkaline because the occasionally flooded forest soils have higher pH (Budke et al., 2008). This indicates that the forest soils in flat plains are more acidic as compared to the Riverine Forest soils in flood plains. The acidic forest soils with the $\mathrm{pH}$ values of 4.33 and 5.26 at $0-15 \mathrm{~cm}$ depth in a community forest and a national forest, respectively, within Udayapur district have also been reported by Paudel and Sah (2003); with the $\mathrm{pH}$ values of 5.6, 5.8 and 6.6 at $0-15 \mathrm{~cm}, 15-30 \mathrm{~cm}$, and $30-45 \mathrm{~cm}$ depths, respectively, in the forest of Sunsari district by Gautam and Mandal (2013); and with the $\mathrm{pH}$ value of 5.36 in the forest of Chitwan district by Chauhan et al. (2014).

\section{Soil Organic Carbon (SOC)}

The percentage of the mean SOC at all depths were found to be the highest $(1.64 \%, 0.96 \%$, and $0.65 \%$ at $0-10 \mathrm{~cm}, 10-20 \mathrm{~cm}$, and $20-30 \mathrm{~cm}$ depths, respectively) in the Terai Shorea Forest followed by the Riverine Forest $(0.79 \%, 0.63 \%$, and $0.54 \%$ at $0-10 \mathrm{~cm}, 10-20 \mathrm{~cm}$, and $20-30 \mathrm{~cm}$ depths, respectively) and the Puraina CF $(0.54 \%, 0.63 \%$, $0.59 \%$ at $0-10 \mathrm{~cm}, 10-20 \mathrm{~cm}$, and $20-30 \mathrm{~cm}$ depths, respectively). Generally, the mean SOC content in the protected areas were found to have decreased with the increase in depth; however, this general trend was not found in the Puraina $\mathrm{CF}$ where the mean SOC content $(0.54 \%)$ in the uppermost layer $(0-10 \mathrm{~cm}$ depth) was lower than those $(0.63 \%$ and $0.59 \%)$ in the deeper layers $(10-20 \mathrm{~cm}$ and $20-30 \mathrm{~cm}$ depths, respectively) (Figure 4). The vertical difference in the mean SOCs was statistically significant $(\mathrm{p}<0.05)$ in the Terai Shorea Forest, but insignificant in the Riverine Forest and the Puraina CF. The difference in the mean SOC sat $0-10 \mathrm{~cm}$ depth in the three studied forests was found to be statistically significant $(\mathrm{p}<$ 0.05 ), but statistically insignificant at $10-20 \mathrm{~cm}$ and $20-30 \mathrm{~cm}$ depths. The mean SOC content (1.64\%) at $0-10 \mathrm{~cm}$ depth in the Terai Shorea Forest was significantly higher as compared to those in the Riverine Forest and the Puraina CF $(0.79 \%$ and $0.54 \%$, respectively, Table 1 ). 
Table 1: Mean $\pm S D$ values of soil parameters at $0-10 \mathrm{~cm}, 10-20 \mathrm{~cm}$, and $20-30 \mathrm{~cm}$ depths in Terai Shorea Forest (TSF), Riverine Forest (RF), and Puraina CF

\begin{tabular}{|c|c|c|c|c|}
\hline \multirow{2}{*}{ Soil Parameters } & \multirow{2}{*}{ Depth } & \multicolumn{3}{|c|}{ Forest Study Area } \\
\hline & & TSF & RF & $\mathrm{CF}$ \\
\hline \multirow[t]{3}{*}{ OC (\%) } & $0-10 \mathrm{~cm}$ & $1.64 \pm 0.65^{\mathrm{a}}{ }_{\mathrm{A}}$ & $0.79 \pm 0.46^{\mathrm{a}}{ }_{\mathrm{A}, \mathrm{B}}$ & $0.54 \pm 0.13^{\mathrm{a}}{ }_{\mathrm{B}}$ \\
\hline & $10-20 \mathrm{~cm}$ & $0.96 \pm 0.41_{\mathrm{a}}^{\mathrm{a}, \mathrm{b}}$ & $0.63 \pm 0.27{ }_{\mathrm{A}}^{\mathrm{a}}$ & $0.63 \pm 0.1{ }_{\mathrm{A}}^{\mathrm{a}}$ \\
\hline & $20-30 \mathrm{~cm}$ & $0.65 \pm 0.15^{\mathrm{b}}{ }_{\mathrm{A}}$ & $0.54 \pm 0.27{ }_{\mathrm{A}}^{\mathrm{a}}$ & $0.59 \pm 0.07{ }_{\mathrm{A}}^{\mathrm{a}}$ \\
\hline \multirow[t]{3}{*}{ TN (\%) } & $0-10 \mathrm{~cm}$ & $0.14 \pm 0.05{ }_{\mathrm{A}}^{\mathrm{a}}$ & $0.09 \pm 0.01_{\mathrm{A}, \mathrm{B}}^{\mathrm{a}}$ & $0.05 \pm 0.01{ }_{\mathrm{B}}^{\mathrm{a}}$ \\
\hline & $10-20 \mathrm{~cm}$ & $0.08 \pm 0.03{ }_{\mathrm{A}}^{\mathrm{b}}$ & $0.06 \pm 0.02^{\mathrm{a}, \mathrm{b}}{ }_{\mathrm{A}}$ & $0.05 \pm 0.01{ }^{\mathrm{a}}{ }_{\mathrm{A}}$ \\
\hline & $20-30 \mathrm{~cm}$ & $0.06 \pm 0.01{ }_{\mathrm{A}}^{\mathrm{b}}$ & $0.05 \pm 0.02{ }_{\mathrm{A}}^{\mathrm{b}}$ & $0.04 \pm 0.01{ }_{\mathrm{A}}^{\mathrm{a}}$ \\
\hline \multirow[t]{3}{*}{$\operatorname{AP}\left(\mathrm{Kg} \mathrm{ha}^{-1}\right)$} & $0-10 \mathrm{~cm}$ & $31.72 \pm 10.66^{\mathrm{a}}{ }_{\mathrm{A}}$ & $12.36 \pm 4.45^{\mathrm{a}}{ }_{B}$ & $12.88 \pm 4.25^{a}{ }_{B}^{a}$ \\
\hline & $10-20 \mathrm{~cm}$ & $16.07 \pm 6.74{ }_{\mathrm{A}}^{\mathrm{b}}$ & $10.82 \pm 3.90{ }_{\mathrm{A}}^{\mathrm{a}}$ & $16.41 \pm 7.68_{\mathrm{A}}^{\mathrm{a}}$ \\
\hline & $20-30 \mathrm{~cm}$ & $14.09 \pm 8.87_{\mathrm{A}}^{\mathrm{b}}$ & $4.84 \pm 5.18_{\mathrm{A}}^{\mathrm{a}}$ & $10.09 \pm 1.68{ }_{\mathrm{A}}^{\mathrm{a}}$ \\
\hline \multirow[t]{3}{*}{$\operatorname{AK}\left(K_{g ~ h a} \mathbf{h a}^{-1}\right)$} & $0-10 \mathrm{~cm}$ & $557.44 \pm 47_{\mathrm{A}}^{\mathrm{a}}$ & $314.9 \pm 35.45^{\mathrm{a}}{ }_{\mathrm{B}}$ & $221.1 \pm 45.77{ }^{\mathrm{a}} \mathrm{C}$ \\
\hline & $10-20 \mathrm{~cm}$ & $525.28 \pm 69.24{ }_{\mathrm{A}}^{\mathrm{a}}$ & $257.95 \pm 50.58{ }_{\mathrm{B}}^{\mathrm{a}}$ & $204.35 \pm 35.24{ }_{B}^{\mathrm{a}}$ \\
\hline & $20-30 \mathrm{~cm}$ & $470.2 \pm 120.62{ }_{\mathrm{A}}^{\mathrm{a}}$ & $241.2 \pm 66.55_{\mathrm{B}}^{\mathrm{a}}$ & $224.45 \pm 58.28^{\mathrm{a}}{ }_{\mathrm{B}}$ \\
\hline \multirow[t]{3}{*}{ pH } & $0-10 \mathrm{~cm}$ & $5.78 \pm 0.05^{\mathrm{a}}{ }_{\mathrm{A}}$ & $7.11 \pm 0.41^{a}{ }_{B}^{a}$ & $6.50 \pm 0.51^{a}{ }_{B}^{a}$ \\
\hline & $10-20 \mathrm{~cm}$ & $5.77 \pm 0.11_{\mathrm{A}}^{\mathrm{a}}$ & $7.25 \pm 0.18^{\mathrm{a}}{ }_{\mathrm{B}}$ & $6.45 \pm 0.47_{\mathrm{C}}^{\mathrm{a}}$ \\
\hline & $20-30 \mathrm{~cm}$ & $5.80 \pm 0.20^{\mathrm{a}}{ }_{\mathrm{A}}$ & $7.36 \pm 0.05^{\mathrm{a}}{ }_{\mathrm{B}}$ & $6.36 \pm 0.54{ }^{\mathrm{a}} \mathrm{A}$ \\
\hline \multirow[t]{3}{*}{ BD $\left(\mathrm{gm} \mathrm{cm}^{-3}\right)$} & $0-10 \mathrm{~cm}$ & $1.46 \pm 0.11^{\mathrm{a}}{ }_{\mathrm{A}}$ & $1.33 \pm 0.15^{\mathrm{a}}{ }_{\mathrm{A}}$ & $1.58 \pm 0.13_{\mathrm{A}}^{\mathrm{a}}$ \\
\hline & $10-20 \mathrm{~cm}$ & $1.58 \pm 0.08{ }_{\mathrm{A}}^{\mathrm{a}}$ & $1.35 \pm 0.10^{\mathrm{a}}{ }_{\mathrm{B}}$ & $1.58 \pm 0.05{ }_{\mathrm{A}}^{\mathrm{a}}$ \\
\hline & $20-30 \mathrm{~cm}$ & $1.58 \pm 0.11_{\mathrm{A}}^{\mathrm{a}}$ & $1.45 \pm 0.10^{\mathrm{a}}$ & $1.63 \pm 0.05^{\mathrm{a}}{ }_{\mathrm{A}}$ \\
\hline \multirow[t]{3}{*}{ Sand (\%) } & $0-10 \mathrm{~cm}$ & $82.79 \pm 11.97{ }_{\mathrm{A}}^{\mathrm{a}}$ & $72.88 \pm 28.42{ }_{\mathrm{A}}^{\mathrm{a}}$ & $84.76 \pm 4.4{ }_{\mathrm{A}}^{\mathrm{a}}$ \\
\hline & $10-20 \mathrm{~cm}$ & $92.31 \pm 5.7_{\mathrm{A}}^{\mathrm{a}}$ & $88.16 \pm 13.12{ }_{\mathrm{A}}^{\mathrm{a}}$ & $77.30 \pm 13.53{ }^{\mathrm{a}}{ }_{\mathrm{A}}$ \\
\hline & $20-30 \mathrm{~cm}$ & $90.77 \pm 5.57{ }_{\mathrm{A}}^{\mathrm{a}}$ & $90.76 \pm 6.81{ }_{\mathrm{A}}^{\mathrm{a}}$ & $85.69 \pm 10.89{ }_{\mathrm{A}}^{\mathrm{a}}$ \\
\hline \multirow[t]{3}{*}{ Silt (\%) } & $0-10 \mathrm{~cm}$ & $6.41 \pm 5.4{ }_{\mathrm{A}}^{\mathrm{a}}$ & $12.56 \pm 13.47{ }_{\mathrm{A}}^{\mathrm{a}}$ & $5.39 \pm 1.21^{\mathrm{a}}{ }_{\mathrm{A}}$ \\
\hline & $10-20 \mathrm{~cm}$ & $6.27 \pm 4.81{ }^{\mathrm{a}}{ }_{\mathrm{A}}$ & $6.82 \pm 8.61{ }^{\mathrm{a}}{ }_{\mathrm{A}}$ & $8.82 \pm 4.88{ }^{\mathrm{a}}{ }_{\mathrm{A}}$ \\
\hline & $20-30 \mathrm{~cm}$ & $5.55 \pm 2.90{ }^{\mathrm{a}}{ }_{\mathrm{A}}$ & $6.65 \pm 5.75^{\mathrm{a}}{ }_{\mathrm{A}}$ & $6.96 \pm 3.96{ }^{\mathrm{a}}{ }_{\mathrm{A}}$ \\
\hline \multirow[t]{3}{*}{ Clay (\%) } & $0-10 \mathrm{~cm}$ & $4.8 \pm 2.59^{\mathrm{a}}{ }_{\mathrm{A}}$ & $14.56 \pm 15.06^{\mathrm{a}}{ }_{\mathrm{A}}$ & $9.85 \pm 3.49{ }^{\mathrm{a}}{ }_{\mathrm{A}}$ \\
\hline & $10-20 \mathrm{~cm}$ & $1.35 \pm 0.84{ }^{\mathrm{a}}{ }_{\mathrm{A}}$ & $5.01 \pm 4.6^{\mathrm{a}}{ }_{\mathrm{A}, \mathrm{B}}$ & $13.87 \pm 9.38^{\mathrm{a}}{ }_{\mathrm{B}}$ \\
\hline & $20-30 \mathrm{~cm}$ & $3.75 \pm 3.33{ }^{\mathrm{a}}{ }_{\mathrm{A}}$ & $1.92 \pm 1.62^{\mathrm{a}} \mathrm{A}$ & $1.356 .94{ }^{\mathrm{a}} \mathrm{A}$ \\
\hline
\end{tabular}

Note: Different letters in superscript (small alphabets) implies significant difference for each soil parameters along a depth gradient for each forest. Different letters in subscript (capital alphabets) implies significant difference in soil parameters between the three forests at a particular depth 


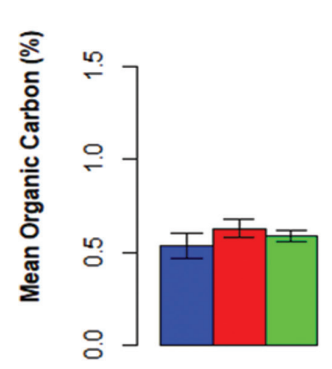

CF

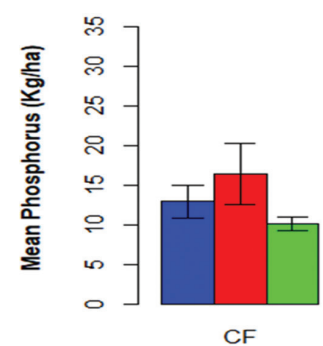

CF

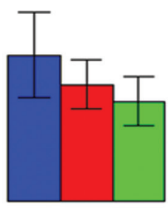

RF

Forest Study Area

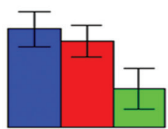

RF

Forest Study Area

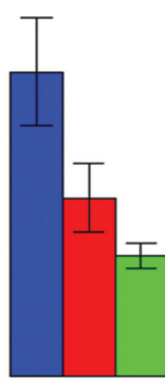

TSF

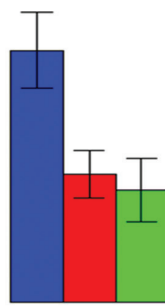

TSF

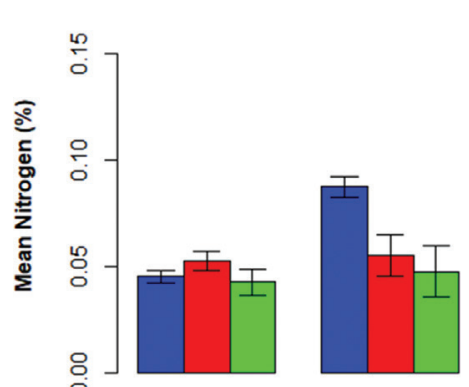

CF

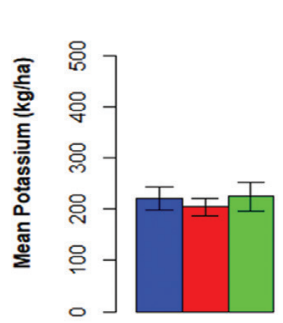

CF

RF Forest Study Area
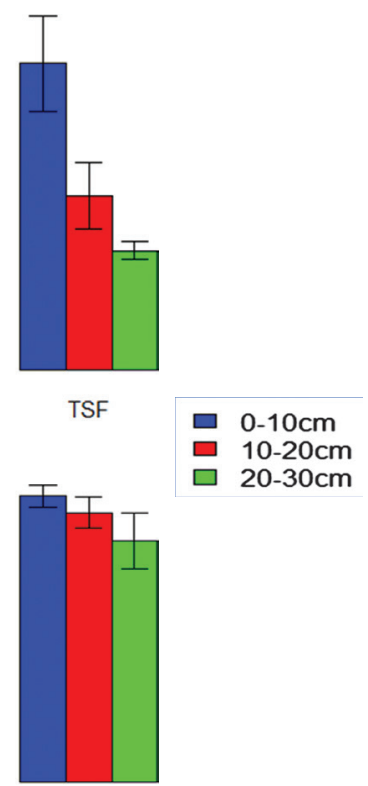

TSF

Figure 4: Diagrammatic representation of the vertical distribution of mean SOC, total nitrogen, available phosphorus and available potassium in three different forest study areas

\section{Total Nitrogen}

The total nitrogen content in the Terai Shorea Forest $(0.14 \%, 0.08 \%$ and $0.06 \%$ at $0-10 \mathrm{~cm}$, $10-0 \mathrm{~cm}$, and $20-30 \mathrm{~cm}$ depths, respectively) were found to be higher than that in the Riverine Forest $(0.09 \%, 0.06 \%$, and $0.05 \%$ at $0-10 \mathrm{~cm}, 10-20 \mathrm{~cm}$, and $20-30 \mathrm{~cm}$ depths, respectively) and the Puraina CF $(0.05 \%, 0.05 \%$, and $0.04 \%$ at $0-10 \mathrm{~cm}$, $10-20 \mathrm{~cm}$, and $20-30 \mathrm{~cm}$ depths, respectively). The vertical differences in the mean soil nitrogen content were statistically significant $(p<0.05)$ in the Terai Shorea and Riverine forests; however, the differences were statistically insignificant in the Puraina CF. The mean soil nitrogen content in the three forest study sites was found to have differed significantly at $0-10 \mathrm{~cm}$ depth, but not so at $10-20 \mathrm{~cm}$ and $20-30 \mathrm{~cm}$ depths. The mean soil nitrogen content at $0-10 \mathrm{~cm}$ depth in the Terai Shorea Forest was significantly higher than that in the Puraina CF (Table 1).

\section{Available Phosphorus}

The mean available phosphorus was found to have decreased with the increase in depth in the Terai Shorea Forest (31.72 $\mathrm{kg} \mathrm{ha}^{-1}, 16.07 \mathrm{~kg}$ ha1 , and $14.09 \mathrm{~kg} \mathrm{ha}^{-1}$ at $0-10 \mathrm{~cm}, 10-20 \mathrm{~cm}$, and $20-30 \mathrm{~cm}$ depths, respectively) and the Riverine Forest $\left(12.36 \mathrm{~kg} \mathrm{ha}^{-1}, 10.82 \mathrm{~kg} \mathrm{ha}^{-1}\right.$, and 4.84 $\mathrm{kg} \mathrm{ha}^{-1}$ at $0-10 \mathrm{~cm}, 10-20 \mathrm{~cm}$, and $20-30 \mathrm{~cm}$ depths, respectively). In the Puraina $\mathrm{CF}$, the mean phosphorus content was highest $\left(16.41 \mathrm{~kg} \mathrm{ha}^{-1}\right)$ at $10-20 \mathrm{~cm}$ followed by $0-10 \mathrm{~cm}\left(12.88 \mathrm{~kg} \mathrm{ha}^{-1}\right)$ and $20-30 \mathrm{~cm}\left(10.09 \mathrm{~kg} \mathrm{ha}^{-1}\right)$. The vertical difference in the mean available phosphorus was statistically significant $(\mathrm{p}<0.05)$ only in the Terai Shorea Forest, and insignificant in the Riverine Forest and the Puraina CF. The mean soil phosphorus contents in the three forest study area were statistically significant $(p<0.05)$ at $0-10 \mathrm{~cm}$ depth; however, insignificant at $10-20 \mathrm{~cm}$ and $20-30 \mathrm{~cm}$ depths. The mean value of the available phosphorus at $0-10 \mathrm{~cm}$ depth in the Terai Shorea Forest was significantly higher than that in the Riverine Forest and Puraina CF (Table 1).

\section{Available Potassium}

The mean available potassium decreased with the increase in depth in the Terai Shorea Forest $\left(557.44 \mathrm{~kg} \mathrm{ha}^{-1}, 525.28 \mathrm{~kg} \mathrm{ha}^{-1}\right.$, and $470.2 \mathrm{~kg}$ $\mathrm{ha}^{-1}$ at $0-10 \mathrm{~cm}, 10-20 \mathrm{~cm}$, and $20-30 \mathrm{~cm}$ depths, respectively) and the Riverine Forest $(314.9 \mathrm{~kg}$ $\mathrm{ha}^{-1}, 257.95 \mathrm{~kg} \mathrm{ha}^{-1}$, and $241.2 \mathrm{~kg} \mathrm{ha}^{-1}$ at $0-10 \mathrm{~cm}$, $10-20 \mathrm{~cm}$, and $20-30 \mathrm{~cm}$ depths, respectively). In the Puraina $\mathrm{CF}$, the decreasing trend of potassium content with the increase in depth $\left(221.1 \mathrm{~kg} \mathrm{ha}^{-}\right.$ 1, $204.35 \mathrm{~kg} \mathrm{ha}^{-1}$, and $224.45 \mathrm{~kg} \mathrm{ha}^{-1}$ at $0-10 \mathrm{~cm}$, $10-20 \mathrm{~cm}$, and $20-30 \mathrm{~cm}$ depths, respectively) 
was not observed. The mean potassium contents at all depths were highest in the Terai Shorea Forest followed by the Riverine forest and the least in the Puraina CF. The vertical differences in the mean potassium content in the three forest study area were found to be statistically insignificant; however, the mean available potassium content in the three studied forests at all depths were found to be statistically significant (Table 1).

In the present study, the mean SOC percent, total nitrogen percent, available phosphorus and available potassium $\left(\mathrm{kg} \mathrm{ha}^{-1}\right)$ decreased with the increase in soil depth in the protected area. Similar decreasing trend of SOC with increase in depth has been reported in a number of literatures (Vsahum et al., 2016; Jabbagy and Jackson, 2000; Dorji et al., 2014). Yang et al. (2010) reported that both SOC and total nitrogen decreased with increase in depth, however the $\mathrm{C}: \mathrm{N}$ ratio did not change. Gautam and Mandal (2013) also observed the decreasing SOC and total nitrogen with the increase in depth in the tropical moist forest of Sunsari, Nepal.

In the Puraina $\mathrm{CF}$, the mean values of the soil nutrients (SOC, total nitrogen, available phosphorus, and available potassium) in the upper most layers were low, and hence the trend of decreased soil nutrients with the increase in soil depth was violated. The lower values of the soil nutrients in the Puraina CF could be probably due to anthropogenic disturbances. The wood and fodder needs of the CF users were mostly met from the extraction of the same from their $\mathrm{CF}$. Forest harvesting caused a sharp decline in the SOC stock as much as $50 \%$ within the first 20 years or more (Johnson, 1992; Davidson and Ackerman, 1993; Lal, 2005). The decline in SOC in harvested forests is probably due to decreased litter input, shifts in composition of woody and herbaceous vegetation, distribution of plant roots, accelerated decomposition and decreased net primary production (Covington, 1981; Johnson et al., 1995; Jackson et al., 2000).

The presence of soil nutrients at all depths in the Terai Shorea Forest was found to be higher than those in the Riverine Forest and the Puraina CF (Table 1). This could be attributed to the natural strains, tree species composition, and management practices adopted in those forests. According to the locals, the Terai Shorea Forest used to encounter summer fire episode while the
Riverine Forest monsoon flooding. On the other hand, the Puraina CF encountered anthropogenic disturbances such as lopping, logging, and resource extraction. The SOC in the present study sites were lower than those $(3.07 \%, 1.34 \%$, and $1.17 \%$ at $0-15 \mathrm{~cm}, 15-30 \mathrm{~cm}$, and $30-45 \mathrm{~cm}$ depths, respectively, in a Sal bearing moist forest in Sunsari district) reported by Gautam and Mandal (2013), and those $(1.86 \%$ and $2.03 \%$ at $0-15 \mathrm{~cm}$ depth, respectively, in a community-managed forest and a protected forest within the Panchase area) reported by Kalu et al. (2014). This could be possibly attributed to the lesser amount of the total precipitation in the present study sites as compared to its occurrence in the Panchase area since SOC increases with increased precipitation (Jabbagy and Jackson, 2000). Duration of monsoon and total precipitation gradually decreases from east to west in Nepal (Bohlinger and Sotreberg, 2017). Despite the difference in total precipitation, the SOC content in the protected Terai Shorea Forest of the present study was similar to those $(1.4 \%$ and $1 \%$ at $0-15 \mathrm{~cm}$ depth in a community-managed forest and a national forest with free access to the local people, respectively in Udayapur district) reported by Paudel and Sah (2003); those $(0.65-2.39 \%$ at $0-30 \mathrm{~cm}$ depth in a communitymanaged forest in Syangja district) reported by $\mathrm{KC}$ et al. (2013); and those $(1.98 \%$ at $0-20 \mathrm{~cm}$ depth in a community-managed forest in Chitwan district) reported by Chauhan et al. (2014). The presence of low amount of SOC in the Puraina CF could be probably due to resource extraction from this $\mathrm{CF}$.

The total nitrogen content at all depths in the present study sites were lower than those $(0.24 \%$, $0.24 \%$, and $0.09 \%$ at $0-15 \mathrm{~cm}, 15-30 \mathrm{~cm}$, and $30-45 \mathrm{~cm}$ depths, respectively, in the Sal bearing moist forest in Sunsari district) reported by Gautam and Mandal (2013), and those $(0.21 \%$ and $0.29 \%$ at $0-15 \mathrm{~cm}$ depth in the community-managed forest and the protected forest, respectively, in the Panchase area) reported by Kalu et al. (2014). The total nitrogen content (at $0-15 \mathrm{~cm}$ depth)in the Terai Shorea Forest was also similar to those $(0.117 \%$ and $0.111 \%$ at $0-15 \mathrm{~cm}$ depth in the community-managed forest and the national forest with free access to the local people, respectively, in Udayapur district) reported by Paudel and Sah (2003); that $(0.09-0.12 \%$ at $0-30 \mathrm{~cm}$ depth in the community-managed forest in Syangja district) reported by KC et al. (2013) and the one $(0.19 \%$ 
at $0-20 \mathrm{~cm}$ depth in the community-managed forest in Chitwan district) reported by Chauhan et al. (2014). This indicated a strong relationship between SOC and total nitrogen.

The available phosphorus in the present study sites were comparatively lower than those (76.64 $\mathrm{kg} \mathrm{ha}^{-1}$ and $79.29 \mathrm{~kg} \mathrm{ha}^{-1}$ at $0-15 \mathrm{~cm}$ depth in the community-managed forest and the national forest with free access to the local people, respectively, in Udayapur district) reported by Paudel and Sah (2003) and that (73.71-93.23 kg $\mathrm{ha}^{-1}$ at $0-30 \mathrm{~cm}$ depth in the community-managed forest in Syangja district) reported by $\mathrm{KC}$ et al. (2013).

The available potassium $\left(2.54-4.23 \mathrm{~kg} \mathrm{ha}^{-1}\right.$ at $0-30 \mathrm{~cm}$ in the community-managed forest in Syangja district) reported by KC et al. (2013), and the one $\left(79.5 \mathrm{~kg} \mathrm{ha}^{-1}\right.$ at $0-20 \mathrm{~cm}$ depth in the Seti Devi CF of Chitwan district) reported by Chauhan et al. (2014) were comparatively lower than that recorded in the present study sites. However, the available potassium (267.73 $\mathrm{kg} \mathrm{ha}^{-1}$ and $233.86 \mathrm{~kg} \mathrm{ha}^{-1}$ at $0-15 \mathrm{~cm}$ depth in the community-managed forest and the national forest, respectively, in Udayapur district) reported by Paudel and Sah (2003) were similar to that in the protected Riverine Forest and the Puraina $\mathrm{CF}$, but lower than the one in the protected Terai Shorea Forest.

\section{Relationship among soil parameters}

The soil nutrients (SOC, total nitrogen, available phosphorus and potassium) showed significant positive correlation $(\mathrm{p}<0.05)$ among themselves (Table 2). The soil $\mathrm{pH}$ value showed significant negative correlation $(\mathrm{p}<0.05)$ with the SOC, total nitrogen, available phosphorus and potassium, and bulk density (Table 2). The percentage of sand was found to be significantly negatively correlated with the percentages of silt and clay (Table 2). However, the percentages of silt and clay showed significant $(0.72, \mathrm{p}<0.05)$ positive correlation.

The SOC, total nitrogen and available phosphorus were found to be negatively correlated with the bulk density and sand content. Available potassium had zero correlation with the soil bulk density and positively correlated with the sand content. The SOC and the available phosphorus were positively correlated to the silt and clay contents. The total nitrogen was positively correlated with the silt while negatively correlated with the clay contents. The available potassium was found to be negatively correlated with the silt and clay contents. The $\mathrm{pH}$ value was negatively correlated with the sand and positively correlated with the silt and clay contents. The soil bulk density was positively correlated with the sand while negatively correlated to the silt and clay contents. However, these correlations were statistically insignificant (Table 2).

\section{Table 2: Pearson Correlation Coefficient values among the soil parameters}

\begin{tabular}{l|l|l|l|l|l|l|l|l|l|}
\hline & OC & TN & AP & AK & pH & BD & Sand & Silt & Clay \\
\hline OC & 1 & $0.94^{*}$ & $0.54^{*}$ & $0.54^{*}$ & $-0.32^{*}$ & -0.14 & -0.19 & 0.22 & 0.01 \\
\hline TN & & 1 & $0.57^{*}$ & $0.58^{*}$ & $-0.33^{*}$ & -0.18 & -0.12 & 0.13 & -0.06 \\
\hline AP & & & 1 & $0.49^{*}$ & $-0.5^{*}$ & -0.12 & -0.1 & 0.04 & 0.09 \\
AK & & & & 1 & $-0.67^{*}$ & 0 & 0.11 & -0.13 & -0.25 \\
pH & & & & 1 & $-0.43^{*}$ & -0.2 & 0.23 & 0.25 \\
BD & & & & & 1 & 0.17 & -0.14 & -0.18 \\
Sand (\%) & & & & & & 1 & $-0.84^{*}$ & $-0.88^{*}$ \\
Silt (\%) & & & & & & & 1 & $0.72^{*}$ \\
Clay (\%) & & & & & & & & 1 \\
\hline
\end{tabular}

Note:- OC : Organic Carbon, TN : Total Nitrogen, AP : Available Phosphorus, AK : Available Potassium, and BD : Bulk Density; ${ }^{*} \mathrm{p}<0.05$

Statistically significant strong positive correlation (0.94) was found between the SOC and the total nitrogen. Similar significant correlation between the SOC and the total nitrogen was also observed by Gautam and Mandal (2013) in the Sal-bearing tropical moist forest of Sunsari district. Positive correlation between the SOC and the total nitrogen was observed by Paudel and Sah (2003) in the forests of Udayapur district and by Chauhan et al. (2014) in Chitwan district. The SOC and the total nitrogen, both showed significant positive relationships with the available phosphorus and the available potassium. The SOC, the total nitrogen, the available phosphorus, the available potassium and the bulk density showed significant negative relationships with the soil $\mathrm{pH}$. The SOC, the total nitrogen and the available phosphorus also showed negative relationships with the soil bulk density while the available potassium showed zero correlation with the soil bulk density, butstatistically insignificant. Similar to our results, Paudel and Sah (2003) had also observed negative correlation of soil $\mathrm{pH}$ with organic matter and nitrogen, positive correlation of organic matter with nitrogen and phosphorus, and positive correlation between nitrogen and potassium. Chauhan et al. (2014) had 
also reported negative correlation between total nitrogen and soil bulk density in Chitwan district.

\section{Conclusion}

In protected forests, SOC, total nitrogen, available phosphorus and available potassium generally decrease with increase in soil depth. However in the Puraina CF, this trend was not observed. The soil nutrients in the Puraina CF were found to be lower than in the protected forests which could be because of the extraction of resources from the $\mathrm{CF}$.

\section{References}

Awasthi, K. D., Singh, B. R., and Sitaula, B. K. 2005. Profile carbon and nutrient levels and management effect on soil quality indictors in Mardi watershed of Nepal. ACTA Agriculture Scandinavia Section B-soil and Plant, 55 (3): 192-204.

Bajracharya, R. M., Sitaula, B. K., Shrestha, B. M., Awasthi, K. D., Balla, M. K. and Singh, B. R. 2004. Soil Organic Carbon Status and Dynamics in the Central Nepal Middle Mountains. Journal of the Institute of Forestry, 12: 28-44.

Blake, G. R. and Hartge, K. H. 1986. Bulk density. In: Methods of Soil Analysis, Part 1: Physical and Mineralogical Methods, Klute, A. (Ed.), $2^{\text {nd }}$ Edition, Agronomy Monograph 9, American Society of Agronomy-Soil Science Society of America, Madison. 363-382.

Bohlinger, P. and Sortberg, A. 2017. A comprehensive view on trends in extreme precipitation in Nepal and their spatial distribution. International Journal of Climatology, 5 (1): 4.

Budke, J. C., Jarenkow, J. A., and Oliveira-Filho, A. T. 2008. Tree community features of two stands of riverine forest under different flooding regimes in Southern Brazil. Flora, 203: $162-174$.

Burke, I. C., Yonker, C. M., Parton, W. J., Cole, C. V., Flach, K., and Schimel, D. S. 1989. Texture, Climate, and Cultivation Effects on Soil Organic Matter Content in U.S.
Grassland Soils. Soil Science Society of America Journal, 53: 800-805.

Chauhan, R. P., Pande, K. R., and Thakur, S. 2014. Soil Properties Affected by Land Use Systems in Western Chitwan, Nepal. International Journal of Applied Sciences and Biotechnology, 2 (3): 265-269.

Covington, W. W. 1981. Changes in forest floor organic matter and nutrient content following clear cutting in northern hardwoods. Ecology, 62: 41-48.

Dahal, N. and Bajracharya, R. M. 2012. Effects of Sustainable Soil Management Practices on Distribution of Soil Organic Carbon in Upland Agricultural Soils of Mid-hills of Nepal. Nepal Journal of Science and Technology, 13 (1): 133-141.

Davidson, E. A. and Ackerman, I. L. 1993. Changes in soil carbon inventories following cultivation of previously untilled soils. Biogeochemistry, 20: 161-193.

Detwiler, R. P. and Hall, C. A. S., 1988. Tropical forests and the global carbon cycle. Science, 239: 42-47.

DoHM. 2019. Climatological records of Nepal. Government of Nepal, Ministry of Energy, Water Resources and Irrigation, Department ofHydrology and Meteorology, Kathmandu, Nepal.

Dorji, T., Odeh, I. O. A., and Field, D. J. 2014. Vertical Distribution of Soil Organic Carbon Density in Relation to Land Use/ Cover, Altitude and Slope Aspect in the Eastern Himalayas. Land, 3: 1232-1250.

Gautam, B. 2019. Physiochemical properties of soil in relation to depth, tree species composition and management practices in western Terai, Nepal. M.Sc. Thesis, Tribhuvan University, Nepal. 24-28.

Gautam, T. P. and Mandal, T. N. 2013. Soil Characteristics in Moist Tropical Forest of Sunsari District, Nepal. Nepal Journal of Science and Technology, 14 (1): 35-40. 
Giri, A., Aryal, B., Ghimire, S. K., Shrestha, K. K., and Jha, P. K. 2001. Vegetation Composition and Biomass Production in Riverine Forest of the Royal Bardia National Park, Nepal. Nepal Journal of Science and Technology, 3: 33-40.

Giri, A., Aryal, B., Bhattarai, B., Ghimire, S. K., Shrestha, K. K., and Jha, P. K. 1999. Vegetation Composition, Biomass Production and Regeneration in Shorea robusta Forests in the Royal Bardia National Park, Nepal. Nepal Journal of Science and Technology, 1: 47-56.

Jabbagy, E. G. and Jackson, R. B. 2000. The vertical distribution of soil organic carbon and its relation to climate and vegetation. Ecological Applications, 10 (2): 423-436.

Jackson, R. B., Schenk, H. J., Jobbagy, E. G., Canadell, J., Colello, G. D., Dickinson, R. E., Field, C. B., Friedlingstein, P., Heimann, M., Hibbard, K., Kicklighter, D. W., Kleidon, A., Neilson, R. P., Parton, W. J., Sala, O. E., and Sykes, M. T., 2000. Belowground consequences of vegetation change and their treatment in models. Ecological Applications, 10: 470-483.

Johnson, C. E., Driscoll, C. T., Fahey, T. J., Siccama, T. G., and Hughes, J. W. 1995. Carbon dynamics following clear cutting of a northern hardwood forest. In: McFee, W., Kelly, J.M. (Eds.). Carbon Forms and Functions in Forest Soils. Soil Science Society American, Madison, WI. 463-487.

Johnson, D. W. 1992. Effects of Forest Management on Soil Carbon Storage. In: Wisniewski, J., Lugo, A.E. (Eds.). Natural Sinks of $\mathrm{CO}_{2}$, Springer, Dordrecht. 83-120.

Kalu, S., Koirala, M., Khadka, U. R., and KC, A. 2014. Soil Quality Assessment for Different Land Use in the Panchase Area of Western Nepal. International Journal of Environmental Protection, 5 (1): 38-43.

KC, A., Bhandari, G., Wagle, S. P., and Banjade, Y. 2013. Status of Soil Fertility in a Community Forest of Nepal. International Journal of Environment, 1 (1): 56-67.
Lal, R. 2005. Forest soils and carbon sequestration. Forest Ecology and Management. 220: 242-258.

Lal, R. 2010. Beyond Copenhagen: mitigating climate change and achieving food security through soil carbon sequestration. Food Security, 2 (2): 169-177.

Paudel, S. and Sah, J. P. 2003. Physiochemical characteristics of soil in tropical sal (Shorea robusta Gaertn.) forests in eastern Nepal. Himalayan Journal of Sciences, 1 (2):107-110.

Shrestha, K. K. and Jha, P. K. 1997. Plant Diversity Analysis and Evaluation of Conservation Measures in the Royal Bardia National Park. Draft Report. World Wildlife Fund (WWF) Nepal Program, Kathmandu. 1-63.

Spain, A. V., Isbell, R. F. and Probert, M. E. 1983. Organic matter contents of Australian soils. In: Soils: An Australian Viewpoint. CSIRO, Melbourne/Academic Press, London. 551-563.

Tale, S. and Ingole, S. 2015. A review on role of physicochemical properties in soil quality. Chemical Science Review and Letters, 4 (13): 57-66.

UNEP, 2012. Annual Report. Retrieved from http:// www.unep.org/annualreporton Jan, 2019.

Vashum, K. T., Kasomwoshi, T., and Jayakumar, S., 2016. Soil organic carbon sequestration potential of primary and secondary forests in Northeast India. Proceedings of the International Academy of Ecology and Environmental Sciences, 6 (3): 67-74.

Walkley, A. and Black, I. A. 1934. An examination of the Degtjareff method for determining soil organic matter, and a proposed modification of the chromic acid titration method. Soil Science, 34: 29-38.

Yang, Y. H., Fang, J. Y., Guo, D. L., Ji, C. J., and Ma, W. H. 2010. Vertical patterns of soil carbon, nitrogen and carbon: Nitrogen stoichiometry in Tibetan grasslands. Biogeosciences, 7: 1-24. 